University of Nebraska - Lincoln

DigitalCommons@University of Nebraska - Lincoln

U.S. Environmental Protection Agency Papers

U.S. Environmental Protection Agency

2009

\title{
The solar transformity of petroleum fuels
}

S. Bastianoni

University of Siena. Via A. Moro 2, 53100 Siena, Italy

D. E. Campbell

United States Environmental Protection Agency

R. Ridolfi

University of Siena. Via A. Moro 2, 53100 Siena, Italy

F. M. Pulselli

University of Siena. Via A. Moro 2, 53100 Siena, Italy

Follow this and additional works at: https://digitalcommons.unl.edu/usepapapers

Part of the Civil and Environmental Engineering Commons

Bastianoni, S.; Campbell, D. E.; Ridolfi, R.; and Pulselli, F. M., "The solar transformity of petroleum fuels" (2009). U.S. Environmental Protection Agency Papers. 9.

https://digitalcommons.unl.edu/usepapapers/9

This Article is brought to you for free and open access by the U.S. Environmental Protection Agency at DigitalCommons@University of Nebraska - Lincoln. It has been accepted for inclusion in U.S. Environmental Protection Agency Papers by an authorized administrator of DigitalCommons@University of Nebraska - Lincoln. 


\title{
The solar transformity of petroleum fuels
}

\author{
S. Bastianoni ${ }^{a, *}$, D.E. Campbell ${ }^{b}$, R. Ridolfi ${ }^{a}$, F.M. Pulselli ${ }^{a}$ \\ a Department of Chemical and Biosystems Sciences, University of Siena. Via A. Moro 2, 53100 Siena, Italy \\ ${ }^{\mathrm{b}}$ United States Environmental Protection Agency, Office of Research and Development, National Health and Environmental Effects \\ Research Laboratory, Atlantic Ecology Division, Narragansett, RI, USA
}

\section{A R T I C L E I N F O}

\section{Article history:}

Received 8 June 2008

Received in revised form

22 August 2008

Accepted 5 September 2008

Published on line 23 October 2008

\section{Keywords:}

Emergy

Specific emergy

Oil derivatives

Refining industry

\begin{abstract}
A B S T R A C T
Petroleum fuels are the primary energy basis for transportation and industry. They are almost always an important input to the economic and social activities of humanity. Emergy analyses require accurate estimates with specified uncertainty for the transformities of major energy and material inputs to economic and environmental systems. In this study, the oil refining processes in Italy and the United States were examined to estimate the transformity and specific emergy of petroleum derivatives. Based on our assumptions that petroleum derivatives are splits of a complex hydrocarbon mixture and that the emergy is split based on the fraction of energy in a product, we estimated that the transformity of petroleum derivatives is $65,826 \mathrm{sej} / \mathrm{J} \pm 1.4 \%$ relative to the $9.26 \mathrm{E}+24 \mathrm{sej} / \mathrm{year}$ planetary baseline. Estimates of the specific emergies of the various liquid fuels from Italian and U.S. refineries are within $2 \%$ of one another and the relationship of particular values varies with the refinery design. Our average transformity is only $1.7 \%$ larger than the current estimate for petroleum fuels determined by back calculation, confirming the accuracy of this transformity in existing emergy analyses. The model uncertainty between using energy or mass to determine how emergy is split was less that $2 \%$ in the estimate of both the transformity and specific emergy of liquid fuels, but larger for solid and gaseous products. This study is a contribution to strengthen the emergy methodology, providing data that can be useful in the analysis of many human activities.
\end{abstract}

() 2008 Elsevier B.V. All rights reserved.

\section{Introduction}

Solar Emergy (from now on simply emergy) is a concept developed by H.T. Odum in the early 1980s to account for the basic energy requirements in obtaining a product. It has been defined as "the available solar energy used up directly and indirectly to make a service or product" (Odum, 1996). The reason why the energy has to be of one particular type (solar) is the totally different ability in performing actual physical work from a joule of different types of energy. Solar energy is then the fundamental unit since it is the basis of all other types of energy in the biosphere.
Emergy expresses all the energy in space and time going into a product. This quantity and the "intensive" quantity, transformity (defined as the solar energy required, in direct and indirect ways, to obtain a joule of product) are the basis of emergy evaluation. Transformity reflects the pathway of energy transformations in the universe, designing an energy hierarchy. Transformities indicate position of each form of energy of the universe in this universal energy hierarchy (Brown et al., 2004).

Since the definitions of emergy and transformity are based more on a logic of "memorization", than of conservation, an algebra of emergy has been introduced. In particular the

\footnotetext{
* Corresponding author. Tel.: +390577 234358; fax: +39 0577234177.

E-mail address: bastianoni@unisi.it (S. Bastianoni). 
difference between the categories of splits and co-products (or by-products) can be expressed as (Brown and Herendeen, 1997):

- By-products from a process have the total emergy assigned to each pathway;

- When a pathway splits, the emergy is assigned to each 'leg' of the split based on its percentage of the total energy flow on the pathway.

Determining the emergy contributed by petroleum fuels is an important factor in almost every emergy evaluation that considers human-dominated systems. The direct use of petroleum fuels may be of variable magnitude, depending on the type of system examined, but its indirect uses support almost every aspect of our industrial-based civilization. In 1995, the use of fossil fuels and minerals accounted for about 2/3 of the emergy basis for the earth (Brown and Ulgiati, 1999). However, in an emergy evaluation of the State of West Virginia Campbell et al. (2005) showed that the petroleum used directly represents $5.3 \%$ of the total emergy used and $7.3 \%$ of the imported emergy. In agricultural production systems petroleum fuel is an important direct input, accounting for between $10 \%$ and $19 \%$ of direct emergy inputs for wine (Pizzigallo et al., 2008), 6.7\% for grain corn, 7.5\% for milk, and $15.6 \%$ for green beans (Brandt-Williams, 2002). Petroleum can be especially important in industrial systems where fuel accounted for $71 \%$ of the emergy required for the production of caustic soda, $48 \%$ for diatomite, and $26 \%$ for $20 \%$ sulphuric acid (Odum et al., 2000). In general, emergy evaluations are sensitive to the quantities and transformities of fuels used to support systems and carry out processes, e.g., fuel type is a fundamental variable in the calculation of the transformity of electricity (Odum, 1996; Brown and Ulgiati, 2002). For this reason, it is important that these values be calculated as precisely as possible.

The transformity of oil was originally derived starting from an average value for the transformity of electricity determined to be $1.73 \mathrm{E}+5 \mathrm{sej} / \mathrm{J}$ (Odum, 1996). ${ }^{1}$ From this number an approximate transformity was derived for coal of $4.3 \mathrm{E}+4 \mathrm{sej} / \mathrm{J}$ assuming $4 \mathrm{coal} \mathrm{J} / \mathrm{J}$ electric power. An additional transformity for coal was determined by analyzing its geological process of formation and found to be $3.4 \mathrm{E}+4 \mathrm{sej} / \mathrm{J}$ resulting in an average estimate of $3.9 \mathrm{E}+4 \mathrm{sej} / \mathrm{J}$ for coal. Rounding this average number to $40,000 \mathrm{sej} / \mathrm{J}$ and multiplying by $1.65 \mathrm{~J} \mathrm{coal} / \mathrm{J}$ motor fuel (Slesser, 1978) gives an estimate of $66,000 \mathrm{sej} / \mathrm{J}$ for fuels derived from oil (Odum, 1996). Cook (1976) found that $19 \%$ of crude oil was used in transport and refining giving a ratio of 1.23 between crude oil and refined products. Odum (1996) estimated the transformity of crude oil to be 54,000 sej/J based on this ratio. Recently, Bastianoni et al. (2005) derived the values of the transformities and emergies per mass of oil and natural gas directly (see Table 1) through an analysis of their geological production process, confirming the results of the

\footnotetext{
1 The numbers given in this paragraph are referenced to the $9.44 \mathrm{E}+24 \mathrm{sej}$ /year baseline (Odum, 1996). To convert them to the $9.26 \mathrm{E}+24 \mathrm{sej} /$ year baseline (Campbell, 2000) used in this paper multiply by 0.9809332 .
}

earlier work by Odum using an independent approach. Now that these values have been verified by several methods, it is fundamental for further development of accurate emergy evaluations, to establish the transformities and emergies per mass of the various fuels derived from oil, through a direct analysis of the refining process.

\subsection{Split or co-product?}

The main factor that influences the value of the transformities of oil-based fuels is the choice between making the various petroleum derivatives splits or co-products in an evaluation of the production process. Emergy is a concept based on the 2nd law of thermodynamics and thus it follows the history of available energy (exergy) use required to create a product or service. In such an accounting, splits and co-products are handled differently, where the sum of the emergy of all co-products can exceed the emergy input. This problem is dealt with by the fourth emergy algebra rule, that states that "Emergy cannot be counted twice within a system:... by-products, when reunited, cannot be added to equal a sum greater than the source emergy from which they were derived" (Brown and Herendeen, 1997).

Being based on "memorization", rather than on conservation logic, emergy evaluation emphasizes knowing the difference between a split and a co-product. In particular, co-products are "product items showing different physicochemical characteristics, but which can only be produced jointly" (Sciubba and Ulgiati, 2005). Splits instead are "originating flows showing the same physico-chemical characteristics" (Sciubba and Ulgiati, 2005).

Petroleum is a complex mixture of hydrocarbons, which is separated into many products in the refining process. There are several problems that can arise in accounting for the emergy delivered by inputs of this type, especially when two or more of them are used in the same production process. If we consider all the oil-derived fuels as a split, in the case of a system supported by several fuels, we can simply add all the emergies of the fuels (since under this assumption they can be considered of independent origin) to obtain the emergy input to the production process. Alternatively, if we consider them as co-products, then only the product with the highest contribution of emergy should be used to determine the emergy input to a fuel-using process. We also considered the hypothesis that petroleum fuels are in a "grey-zone" between a split and a co-product. In this case the best way to estimate the transformities of oil derivatives would be from production processes that have been adjusted for the maximum yield of a particular derivative. In this approach, a problem arises in determining how to sum the emergy contributions to determine the total emergy required by a fuel-using process when more than one fuel from the same source is used: all the contributions should be added and then the "intersection" of the emergies (i.e. the part of the emergy that is in common between one fuel and another) should be subtracted. This calculation could be quite difficult to handle. This paper aims to clarify the production of petroleum derivatives in the refining process and to produce reliable transformities and specific emergies (emergy per unit mass) of the various fuels to be used in other emergy evaluations. 
tion at these five refineries was evaluated from 1996 to 1998 and the results were used to estimate the emergy of goods and services used for refining in the U.S. industry as a whole.

Data on the U.S. refining industry was obtained from EIA (2007) Energy Information Administration web site (http://tonto.eia.doe.gov/dnav/pet/pet_pnp_top.asp). Data on the weekly inputs in barrels from 1993 to 2004 were summed to obtain the annual utilization of crude oil and additives in the U.S. refining industry: the average annual input of crude oil was 5.35 billion barrels. The volumes of outputs were calculated from the percentage yield of products in 16 categories plus a processing gain in volume. There were 10 categories of liquids (liquefied petroleum gas - LPG - motor gasoline, aviation gasoline, kerosene-jet fuel, kerosene, distillates, residual fuel oil, naphtha chemical feedstock, other chemical feedstock and naphtha special), four solids (lubes, waxes, petroleum coke, and asphalt), one gas (still gas), plus one miscellaneous category. The small amount of miscellaneous material was assumed to be solids. The mass of output products was determined by applying an average weight per barrel to the volume data. These factors were also obtained from EIA (2005) (www.eia.doe.gov/emeu/iea/tablec1.html). The weighted average barrels per metric ton ( $t$ ) was determined for all the products and applied to the crude oil and additive volume input to estimate the weight of crude oil used. In particular in the years 1993-2004 the U.S. refining industry produced $46.3 \%$ gasoline, $22.8 \%$ distillates (mainly diesel) and around $10 \%$ kerosene and jet fuels.

The inputs of energy and materials to the refining process including the feedback of refined products were given in EIA (2004) Petroleum Supply Annual 2004 Volume 1 http://www.eia.doe.gov/oil_gas/petroleum/data_publications/ petroleum_supply_annual/psa_volume1/psa_volume1.html.

Also in this case, the transformity of crude oil and of natural gas are according to Table 1, while for the transformity of coal we used 39,200 sej/J (Campbell et al., 2005). The emergy of services in the crude oil extracted and transported to the U.S. was estimated from the average cost for oil on the world market from 1946 to 2006, which was used to convert the dollar value of the oil to an estimate of the emergy of human service required to extract and transport it to the refinery. The emergy of human services used in the refining process in the United States was estimated from an analysis of five refineries in the San Francisco Bay area (Quinn, 2001). The emergy of labor was estimated separately using employment data and subtracted from the total input of all goods and services to avoid double counting. This evaluation of the San Francisco Bay area refineries used data on the material inputs to production from the 2004 analysis of the entire U.S. Refining industry, which were applied to the Bay area refineries assuming that the requirement for material inputs per $t$ of gasoline produced was the same as for the nation in 2004.

\section{Results and discussion}

\subsection{Solution of split/co-product dilemma}

Crude oil is a complex mixture of mainly hydrocarbons that comes out of the ground in many different forms. Based on the demand for petroleum products that exists in a given region and the availability of the various kinds of crude oil (sweet, sour, light, heavy) refineries are constructed to take and refine crude oil within a certain range of properties, e.g., specific gravity, sulphur content, boiling point of the constituents, etc. From the description of the interaction of crude oil input with the refinery system given above, we have seen that the range of proportions among the possible products is in principle very wide. Only after the plant is established are the proportions of the output products constrained by the refinery characteristics. Even after the refinery is built, it can be converted to process a different kind of crude oil by refitting it, even though the cost can be high.

In the refining process petroleum derivatives behave like splits, because the input is a complex mixture of hydrocarbons and the output is a separation of this mixture into fractions of different density. In principle all of the hydrocarbons, thus derived, can be used for the same purpose, i.e., they are combustible, however the best use for some of the solid products may be for other purposes, i.e., lubrication, constructing impervious surfaces, etc. The fact that some petroleum derivatives are best used for different purposes introduces the possibility that they may be legitimately considered as co-products. However, in nature the hydrocarbons in petroleum can be converted into various proportions of the various constituents of the mixture depending on the conditions of heat pressure, and confinement experienced by the material. Under high enough conditions of heat and pressure deep within the earth all petroleum is converted to natural gas (Tissot and Welte, 1978) illustrating that its essential nature is that of a single material. Therefore we conclude that the weight-of-evidence given above indicates that the density separation of crude oil into oil-based fuels is more similar to a split than it is to a coproduct.

Now we have to choose between a pure split and the "grey-zone" hypotheses presented above, which introduces elements of the co-product algebra into the calculation. The former is much easier to use, while the latter is perhaps more precise, since the possibility of producing each different fuel in the refining process is not exactly $100 \%$. The choice can be made in favour of the pure split hypothesis only if the error in this assumption is reasonably low. Since the cost of treatment is the main factor allowing flexibility in the established production process, the question becomes, "Is it reasonable to assume that this cost does not influence the results too much?" We performed an emergy evaluation of the Falconara plant in Italy (Table 2) to help answer this question. The diagram of the plant is given in Fig. 1, where all the inputs to the process are visualized. The monetary value of oil was included to consider all the costs due to extraction, transportation, etc. These calculations showed that all the emergy investments (equipment, maintenance and methane) to run the refinery processes amount to around $4 \%$ of the total emergy required to produce the products. Thus, the emergy investment in processing is small (not the economic one!) compared to the emergy of the products and we can consider the products of the refining process as splits without introducing an unacceptable uncertainty into the calculation. 
Table 2 - Emergy evaluation of fuels in Falconara API refinery (Italy), referred to $1 \mathrm{t}$ of crude oil in input.

\begin{tabular}{llcccc} 
Note & \multicolumn{1}{c}{ Category and item } & Raw data & Units & Emergy/unit (sej/unit) & Emergy (sej) \\
\hline 1 & Oil & 1 & $\mathrm{t}$ & $2.27 \mathrm{E}+15$ & $2.27 \mathrm{E}+15$ \\
2 & Methane (internal consumptions) & $1.04 \mathrm{E}+09$ & $\mathrm{~J}$ & $4.35 \mathrm{E}+04$ & $4.53 \mathrm{E}+13$ \\
3 & Maintenance & 20.0 & $€$ & $1.43 \mathrm{E}+12$ & $2.86 \mathrm{E}+13$ \\
4 & Equipment + rest of the refinery & 22.5 & $€$ & $1.43 \mathrm{E}+12$ & $3.22 \mathrm{E}+13$ \\
5 & Acquisition cost $(26.16 \$ /$ barrel) & 153.5 & $€$ & $1.37 \mathrm{E}+12$ & $2.10 \mathrm{E}+14$ \\
6 & Fuels & $3.89 \mathrm{E}+10$ & $\mathrm{~J}$ & 66,490 & $2.59 \mathrm{E}+15$ \\
\hline
\end{tabular}

The fuels produced are considered as a split in energy. Transformities are according to the $9.26 \mathrm{E}+24$ sej/year baseline. Previous transformity of a generic petroleum derived fuel was $64,742 \mathrm{sej} / \mathrm{J}$ (which is equal to $66,000 \mathrm{sej} / \mathrm{J}$, when referred to the $9.44 \mathrm{E}+24 \mathrm{sej} / \mathrm{year} \mathrm{baseline}$ ). Note 1 : Total quantity of oil treated in 1 year: 3,643,093 t, but the analysis is referred to $1 \mathrm{t}$ of crude oil in input. Note 2: Methane (for refinery processes): $3.80 \mathrm{E}+15 \mathrm{~J}$ (assuming 1.04E+09 J/t). Note 3: Maintenance: $20.0 € / \mathrm{t}$. Note 4: Equipment and other costs: $22.5 € / \mathrm{t}$. Note 5 : Acquisition cost: $2.62 \mathrm{E}+01 \$ / \mathrm{barrel}$, equal to $153.5 € / \mathrm{t}(1 €=1.2439 \mathrm{US} \$$ in $2004 ; 1 \mathrm{t}=7.3$ barrels). Note 6 : Total fuels, excluding gases for internal use, produced by Falconara Plant (average 2001-2004): gasoline, 2.87E+16J; diesel, 7.23E+16 J; residual fuel oil, 1.49E+16J; LPG, 6.10E+15J; Bitumen, 1.97E+16 J; total fuels, 1.42E+17 J; fuels per $t$ of oil in input, $1.42 \mathrm{E}+17 \mathrm{~J} / 3.63 \mathrm{E}+6 \mathrm{t}=3.89 \mathrm{E}+10 \mathrm{~J} / \mathrm{t}$.

\section{2. $\quad$ Split in mass or in energy?}

Now that we have given evidence that oil derived fuels reasonably can be considered splits, we must determine if the split should be made in terms of energy or mass. The former (an energy-based split) is supported by the fact that energy must be conserved and that, while all fuels would have the same transformity, the emergy per mass of the lower quality outputs (lower heat content) would be lower. A split based on energy may also be justified by considering the production process for crude oil. If we assume that crude oil constituents with greater enthalpy require more transformations of energy in geological processing, they should have higher transformities (or emergy per mass, as in this case).

In support of the latter hypothesis (a mass split) is the fact that oil refining is a process based on distillation (density separation) of a complex mixture. Nonetheless there are two main drawbacks to the mass split:

(1) We would obtain different transformities for the different fuels by dividing the common emergy per mass of the generic fuel by the energy content per unit mass of each fuel. However, we would obtain higher transformities for lower quality fuel outputs, i.e., fuels with lower calorific

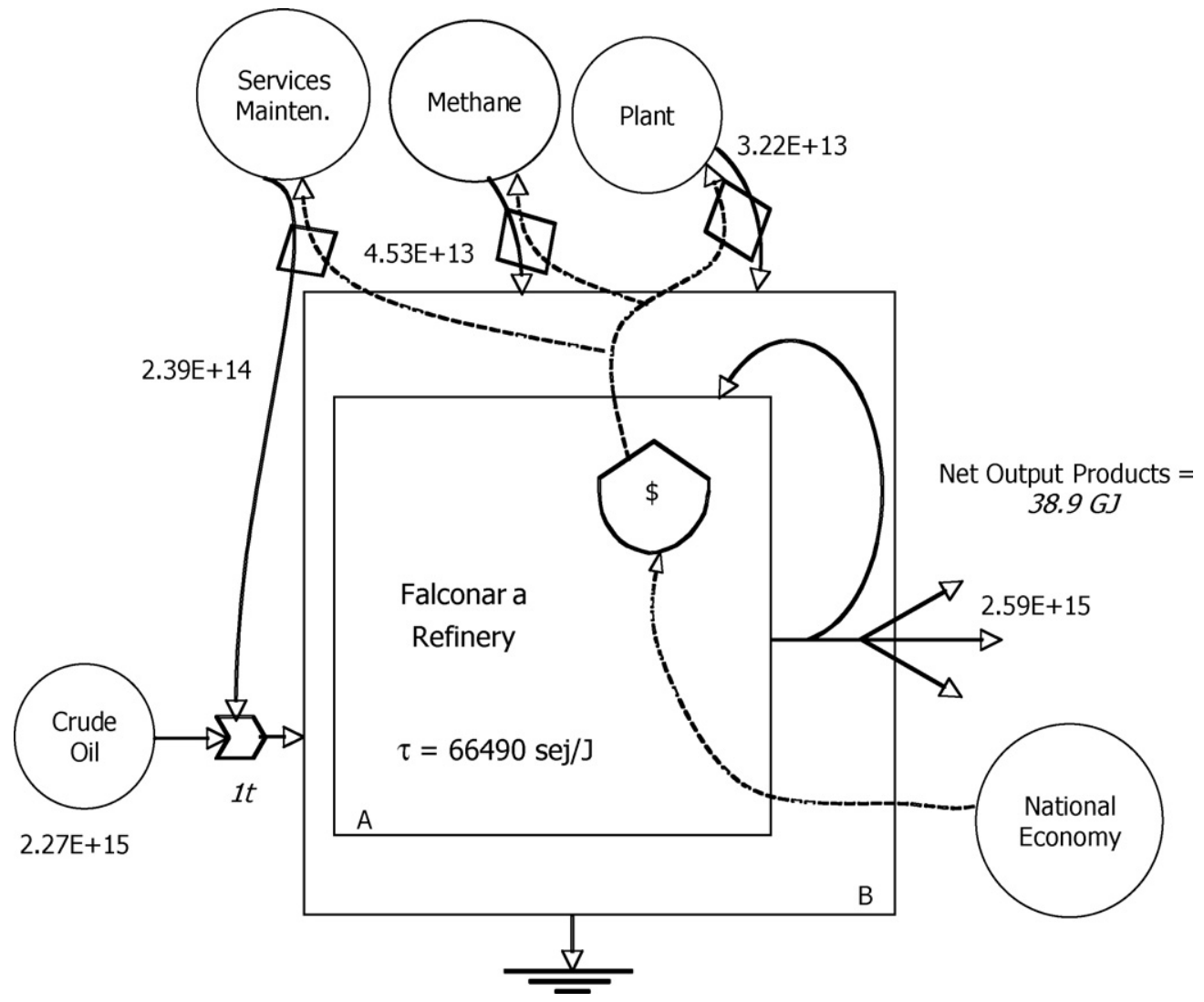

Fig. 1 - An energy diagram of the Falconara refinery system (emergies of the inputs - in sej - are in bold). The analysis was performed using boundary $\mathrm{B}$. Tau, $\tau$, represents the transformity of the generic oil derivative. 
Table 3 - Emergy analysis of the U.S. refining industry in 2004.

\begin{tabular}{|c|c|c|c|c|c|}
\hline Note & Category and item & Raw data & Units per year & Emergy/unit $^{\mathrm{a}}$ (sej/unit) & Emergy (sej/year) \\
\hline \multicolumn{6}{|c|}{ Inputs } \\
\hline 1 & Crude oil \& additives & $3.47 \mathrm{E}+19$ & $\mathrm{~J}$ & 54,200 & $1.88 \mathrm{E}+24$ \\
\hline 2 & Service in crude oil & $1.54 \mathrm{E}+11$ & $\$$ & $1.07 \mathrm{E}+12$ & $1.64 \mathrm{E}+23$ \\
\hline 3 & Natural gas & $7.42 \mathrm{E}+17$ & J & 43,500 & $3.23 \mathrm{E}+22$ \\
\hline 4 & Electricity & $1.31 \mathrm{E}+14$ & $J$ & 170,400 & $2.23 \mathrm{E}+22$ \\
\hline 5 & Coal & $1.00 \mathrm{E}+15$ & $\mathrm{~J}$ & 39,200 & $3.92 \mathrm{E}+19$ \\
\hline 6 & Steam & $2.93 \mathrm{E}+10$ & $\mathrm{~g}$ & $1.30 \mathrm{E}+09$ & $3.80 \mathrm{E}+19$ \\
\hline 7 & Goods and services ${ }^{b}$ & & & & $3.50 \mathrm{E}+22$ \\
\hline \multicolumn{6}{|c|}{ Internal feedbacks } \\
\hline 8 & LPG & $1.45 \mathrm{E}+16$ & $\mathrm{~J}$ & & \\
\hline 8 & Distillate & $4.70 \mathrm{E}+15$ & $\mathrm{~J}$ & & \\
\hline 8 & Residual fuel oil & $1.33 \mathrm{E}+16$ & $\mathrm{~J}$ & & \\
\hline 8 & Petroleum coke & $5.35 \mathrm{E}+17$ & $\mathrm{~J}$ & & \\
\hline 8 & Refinery gases & $1.05 \mathrm{E}+18$ & $J$ & & \\
\hline \multicolumn{6}{|c|}{ Outputs } \\
\hline 9 & Fuels (net output) & $3.27 \mathrm{E}+19$ & $\mathrm{~J}$ & 65,256 & $2.13 \mathrm{E}+24$ \\
\hline
\end{tabular}

Note 1: Weekly crude oil and additive inputs in 1000 barrels (EIA web site accessed 2/2007) were converted to $t$ and then to energy in J assuming that crude oil and the additives were similar in weight and calorific value. Conversion factors were 7.33 barrels per $\mathrm{t}$ of crude oil and $43,370 \mathrm{~J} / \mathrm{g}$. The transformity of crude oil is the average of the values obtained by Bastianoni et al. (2005) and Odum (1996). Note 2: In 2004 oil sold for an average price of $\$ 34.16$ per barrel. However, we chose to use the long-term average price from 1949 to 2006 because we believe it to be a better indicator of the goods and services required for extraction and transportation. The emergy to dollar ratio for the U.S. in 2000, $1.07 \mathrm{E}+12 \mathrm{sej} / \$$, was used to convert the dollars paid for the oil to emergy assuming that U.S. average value of human service was appropriate to estimate the emergy needed to extract and transport the oil to the refineries. Note 3: Natural gas use in the U.S. refining industry was $6.75 \mathrm{E}+11 \mathrm{cu} . \mathrm{ft}$ in 2004 (Table 37 in EIA, 2004). We used an average energy content of 1.1E6J/cu.ft and 43,500 sej/J (the average of Bastianoni et al. (2005) and Odum (1996)) was used to convert cubic feet of natural gas to emergy. Note 4: The U.S. refining industry used 3.64E+10 kWh of electricity in 2004. We converted this value to J and applied the transformity 170,400 sej/J (Campbell et al., 2005). Note 5: The U.S. refining industry used 3.40E+10 g of coal in 2004. We assumed an average energy content of 29,400 J/g and a transformity of 39,200 sej/J (Campbell et al., 2005). Note 6: The specific emergy of steam was determined from an emergy analysis of a combined cycle natural gas power plant (Raugei et al., 2005). A rough value for industrial steam was obtained as follows: Exergy of the fuel $3.80 \mathrm{E}+16 \mathrm{~J}$, grams of steam delivered $1.27 \mathrm{E}+12 \mathrm{~g}$, transformity of natural gas, $43,500 \mathrm{sej} / \mathrm{J}$; the specific emergy of steam to run the turbines is then $1.65 \mathrm{E}+21 \mathrm{sej} / 1.27 \mathrm{E}+12 \mathrm{~g}$ steam or $1.3 \mathrm{E}+9 \mathrm{sej} / \mathrm{g}$. Note 7 : The dollar value of goods and services purchased was estimated from the goods and services required per $t$ of gasoline produced at 5 San Francisco Bay Refineries from 1996 to 1998 . The U.S. emergy to dollar ratio for 1997, 1.20E+12 sej/\$, was used to estimate the emergy of the goods and services required to refine a t of gasoline. Note 8: Fuel use data from Table 37 in EIA/Petroleum Supply Annual 2004, Volume 1. This data includes all fuel use and all non-processing losses of crude oil and petroleum products including spills, fires, contamination, etc. Note 9: This includes 3.23E+8t of gasoline, for the production of which the system is optimized.

${ }^{a}$ Emergy per unit values are relative to the $9.26 \mathrm{E}+24$ sej/year planetary baseline (Campbell, 2000).

$\mathrm{b}$ Extrapolated from the emergy of goods and services, labor and investments needed per t of gasoline in San Francisco refineries (see Table 4).

value, which is a result that would be inconsistent with theory, if the products are different.

(2) Under certain circumstances it might be possible to violate the energy conservation principle (1st law of thermodynamics), since we could (in principle) "choose" to obtain only the highest calorific value products (e.g. gas) and therefore create energy with respect to the average barrel of oil used as input (i.e. a set of products with a total energy content higher than the energy content of a barrel of crude oil).

Therefore, we assigned emergy in the split of crude oil constituents in refining on an energy basis. If done in this manner the transformity of the constituents will be the same, and the difference in specific emergies reflects the relative effectiveness of their action in use.

\subsection{Calculation of transformities and specific emergies}

The results of our analyses are presented in the following order: (i) The Falconara calculations and results, i.e., transformity of the generic fuel.

(ii) Analysis of the U.S. refining industry (average 1993-2004),

(iii) Estimation of the average energy and material inputs to the U.S. refining industry from 1993 to 2004 based on a complete analysis using 2004 data and estimation of services in the U.S. refining industry from 1993 to 2004 using data from 5 refineries in the San Francisco Bay area.

(iv) Results of U.S. 1993-2004 refining industry (transformity of generic fuel).

(v) Comparison of U.S 1993-2004 results with Falconara results and calculation of the average of transformity and specific emergies (emergy per mass).

(i) The total emergy supporting the process of refining $1 \mathrm{t}$ of oil in the Falconara plant is $2.59 \mathrm{E}+15 \mathrm{sej}$ (Table 2), around $95 \%$ of which is directly or indirectly due to the crude oil input (including extraction and transportation costs). The energy content of the mix of outputs is $3.89 \mathrm{E}+10 \mathrm{~J} / \mathrm{t}$ of input. The common transformity for the fuels obtained in the Falconara plant is therefore $66,490 \mathrm{sej} / \mathrm{J}$ (Table 2). 


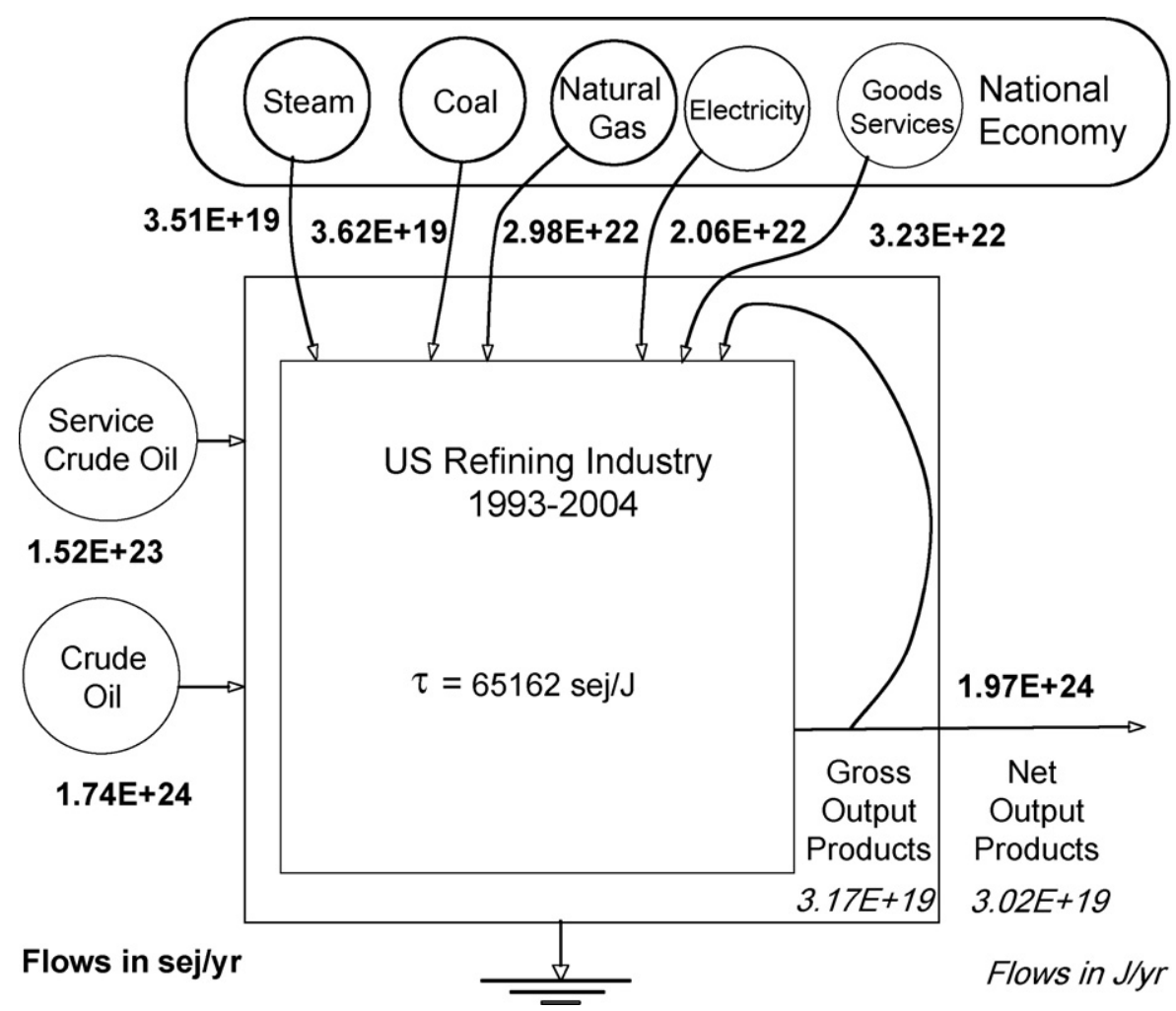

Fig. 2 - Energy diagram of the U.S. refining industry (1993-2004). Emergies are in bold; energies in italic. Tau, $\tau$, represents the transformity of the generic oil derivative.

(ii) An Emergy evaluation for the U.S. refining industry from 1993 to 2004 is represented in Fig. 2, in which all the inputs and their emergy content are shown. Since the whole set of data for the periods 1993-2004 was not available, estimates of the material and energy inputs required for refining crude oil in the U.S. industry were taken from detailed data for 2004 (Table 3), while an estimate of goods and services used by the U.S. refining industry was extrapolated from an analysis of 5 refineries in the San Francisco Bay area (see Table 4, data from Quinn, 2001).

(iii) Data from the five refineries in San Francisco area (1996-1998) demonstrated that the cost of refining oil in the United States was a small part (around 2\%) of the emergy contained in the products (inputs 7-9 in Table 4). From Table 4 we deduced an emergy input from goods \& services, investment and human labor per $t$ of gasoline (the output for which the plant is optimized, $1.87 \mathrm{E} 7 \mathrm{t} /$ year) of $1.08 \mathrm{E}+14 \mathrm{sej} / \mathrm{t}$ of gasoline. This result led to the estimate of the emergy of goods \& services, investment and human labor for U.S. refining industry in 2004 (input 7 in Table 3). The values of the transformity in these two cases are calculated but not used in this paper. They can be used in particular cases since they are site specific (San Francisco Bay area, with a transformity of $64,527 \mathrm{sej} / \mathrm{J}$ of generic fuel) or referred to 1 year (U.S. 2004, with a transformity of $65,256 \mathrm{sej} / \mathrm{J}$ of generic fuel). (iv) The material and energy inputs other than crude oil for the U.S. refining industry (1994-2004) were extrapolated from the analysis of 2004 (Table 3), considering the ratios of each input to crude oil (in 2004) and multiplying them by the average amount of crude oil in 1993-2004. Material and energy inputs represent $2.56 \%$ of the total emergy, while $1.64 \%$ of the emergy inputs are from investments, services and labor, corroborating the results of the analysis of Falconara. In contrast, $7.7 \%$ of the emergy required is supplied by the services of extracting and transporting the oil to the refinery and the remainder (around 88\%) resides in the crude oil itself (Fig. 2).

The total average emergy driving the U.S refining industry in the periods $1993-2004$ is $1.97 \mathrm{E}+24 \mathrm{sej} /$ year. In the same period the net output of the system was 3.02E+19J/year that implies an average transformity for petroleum derivatives equal to $65,162 \mathrm{sej} / \mathrm{J}$.

(v) The transformity of the generic fuel for the U.S. refining industry (1993-2004) is around 2\% lower than the estimate for fuels produced at Falconara $(66,490 \mathrm{sej} / \mathrm{J})$. This difference is practically negligible and leads to an average transformity of $65,826 \mathrm{sej} / \mathrm{J}$, with a standard error of $1.4 \%$. This value is only $1.7 \%$ higher than the transformity obtained by Odum $(64,742 \mathrm{sej} / \mathrm{J}$ according to $9.26 \mathrm{E}+24 \mathrm{sej} /$ year baseline) by means of considerations on 
Table 4 - Emergy analysis of five San Francisco Bay Refineries (1996-1998).

\begin{tabular}{|c|c|c|c|c|c|}
\hline Note & Category and item & Raw data & Units per year & Emergy/unit ${ }^{a}$ (sej/unit) & Emergy (sej/year) \\
\hline \multicolumn{6}{|c|}{ Material inputs } \\
\hline 1 & Crude oil \& additives & $1.59 \mathrm{E}+18$ & $\mathrm{~J}$ & 54,200 & $8.63 \mathrm{E}+22$ \\
\hline 2 & Natural gas & $4.26 \mathrm{E}+16$ & $\mathrm{~J}$ & 43,500 & $1.85 \mathrm{E}+21$ \\
\hline 3 & Electricity & $7.51 \mathrm{E}+12$ & $\mathrm{~J}$ & 170,400 & $1.28 \mathrm{E}+21$ \\
\hline 4 & Coal & $5.73 \mathrm{E}+13$ & $\mathrm{~J}$ & 39,200 & $2.25 \mathrm{E}+18$ \\
\hline 5 & Steam & $1.68 \mathrm{E}+09$ & g & $1.30 \mathrm{E}+09$ & $2.18 \mathrm{E}+18$ \\
\hline \multicolumn{6}{|c|}{ Service inputs } \\
\hline 6 & Service in crude oil & $4.61 \mathrm{E}+09$ & $\$$ & $1.20 \mathrm{E}+12$ & $5.53 \mathrm{E}+21$ \\
\hline 7 & Goods and services & $8.21 \mathrm{E}+08$ & $\$$ & $1.2 \mathrm{E}+12$ & $9.86 \mathrm{E}+20$ \\
\hline 8 & Labor & $1.43 \mathrm{E}+13$ & $\mathrm{~J}$ & $4.80 \mathrm{E}+07$ & $6.60 \mathrm{E}+20$ \\
\hline 9 & Investment & $3.00 \mathrm{E}+08$ & $\$$ & $1.2 \mathrm{E}+12$ & $3.60 \mathrm{E}+20$ \\
\hline \multicolumn{6}{|c|}{ Internal feedbacks } \\
\hline 10 & LPG & $8.33 \mathrm{E}+14$ & $\mathrm{~J}$ & & \\
\hline 10 & Distillate & $2.70 \mathrm{E}+14$ & $\mathrm{~J}$ & & \\
\hline 10 & Residual fuel oil & $7.65 \mathrm{E}+14$ & $\mathrm{~J}$ & & \\
\hline 10 & Petroleum coke \& gases & $8.81 \mathrm{E}+16$ & $\mathrm{~J}$ & & \\
\hline \multicolumn{6}{|c|}{ Outputs } \\
\hline 11 & Fuels (net output) & $1.50 \mathrm{E}+18$ & $\mathrm{~J}$ & 64,527 & $9.70 \mathrm{E}+22$ \\
\hline
\end{tabular}

Note 1: Crude oil and additive use by 5 major San Francisco Bay area refineries in 1998 reported as 294,001 thousand barrels (Quinn, 2001). The weight of crude oil was determined from the weighted average of the products and its energy using 43,370 J/g and 7.33 barrels per t. Note 2: Natural gas used per $\mathrm{t}$ of gasoline produced in the U.S. refining industry in $2004(2087.63 \mathrm{cu} . \mathrm{ft} / \mathrm{t})$ was used to estimate Bay area refinery gas use. We used an average energy content of 1.1E+6 J/cu.ft and 43,500 sej/J (average of Bastianoni et al., 2005; Odum, 1996) to convert cubic feet of natural gas to emergy. Note 3: Electricity use per $t$ of gasoline produced in the U.S. refining industry in $2004(4.05 \mathrm{E}+8 \mathrm{~J} / \mathrm{t})$ was used to estimate electricity used by the Bay area refineries. See Table 3 corresponding note. Note 4: Coal use per t of gasoline produced in the U.S. refining industry in $2004(105.1 \mathrm{~g} / \mathrm{t})$ was used to estimate Bay area refinery use. See Table 3 corresponding note. Note 5: Steam use per $\mathrm{t}$ of gasoline produced in the U.S. refining industry in $2004(90.6 \mathrm{~g} / \mathrm{t})$ was used to estimate Bay area refinery use. See Table 3 corresponding note. Note 6: A value for crude oil and additives was reported by Quinn (2001) for 1996-1998. We used the average value for these 3 years. The emergy to dollar ratio for the U.S in 1997 (Campbell et al. (2005) was used to convert the dollars paid for the oil to an estimate of the emergy used in extraction and transportation. Note 7: The monetary value of goods and services purchased was reported by Quinn (2001) as 1.1 billion dollars. We reduced this cost by the value of labor to avoid double counting. Note 8: The joules of labor required per year were calculated based on $2500 \mathrm{kcal} / \mathrm{day}$ for human labor and a 6-day work week with 2 weeks of paid vacation. The transformity of labor was taken as an average between college and high school (Odum, 1996; Campbell et al., 2005). Note 9: Quinn (2001) gives an average of $\$ 300,000$ per year in investment. Note 10: Use of internal feedbacks in San Francisco Bay area refineries was estimated on the basis of the amount of feedbacks needed per t of gasoline produced in the U.S. refining industry in 2004. Note 11: This includes 1.85E+7 t of gasoline, for the production of which the plants are optimized.

${ }^{a}$ Emergy per unit values are expressed relative to the $9.26 \mathrm{E}+24 \mathrm{sej} /$ year planetary baseline (Campbell, 2000).

the different efficiencies of coal and oil in electricity production (see Odum, 1996).

In order to obtain the (different) values of the emergy per mass of the different fuels we used the IPCC (2006) classification and data of calorific values (Table 5). High enthalpy refinery gases have the highest specific emergy value (average $3.26 \mathrm{E}+9 \mathrm{sej} / \mathrm{g}$ ), while low calorific value products (e.g. bitumen and lubricants) have an average emergy per mass of $2.634 \mathrm{E}+9 \mathrm{sej} / \mathrm{g}$; the most commonly used fuels, gasoline and diesel, have average emergy per mass $2.92 \mathrm{E}+9$ and $2.83 \mathrm{E}+9 \mathrm{sej} / \mathrm{g}$, respectively (Table 5).

\subsection{Evaluation of the uncertainty of the energy versus} mass split models using 2004 data from the U.S. refining industry

Now that the final results are given, we introduce a section in which we investigate the effects of the choices we made on the results. For example, to better understand the role of model uncertainty, we provide a white box representation (in which splits feeding back in the production process are explic- itly accounted for), using an energy versus a mass split in the evaluation of transformities and specific emergies for the U.S. refining industry in 2004 (Fig. 3a and b). Table 3 shows the calculation of transformity for liquid fuels derived from the energy split model using 2004 data for U.S. refineries. In this case all the feedbacks were neglected and only the net output was considered for the calculation of transformity and emergy per mass. When using a white box model, the main output (liquid fuels) is determined as result of the external inputs plus the internal feedbacks from solids and gases, leading to a transformity for liquids of 65,636 sej/J (Fig. 3a). The energy split assumption gives liquid fuels the highest transformity with solids and gases each having the same slightly lower ( $5 \%)$ transformity (Fig. 3a). The fact that liquids and solids-gases have different transformities is due to the fact that gases and solids are fed back to the system in order to produce liquids (the main target of a refinery), therefore adding their emergy to the production process. The specific emergies follow a trend with liquid fuels having a specific emergy considerably greater than solids $(\sim 25 \%)$, but less than gases $(\sim 7 \%)$ consistent with the higher heat value per unit mass for the gas. Nevertheless transformities of gases and solids are not significant since the 

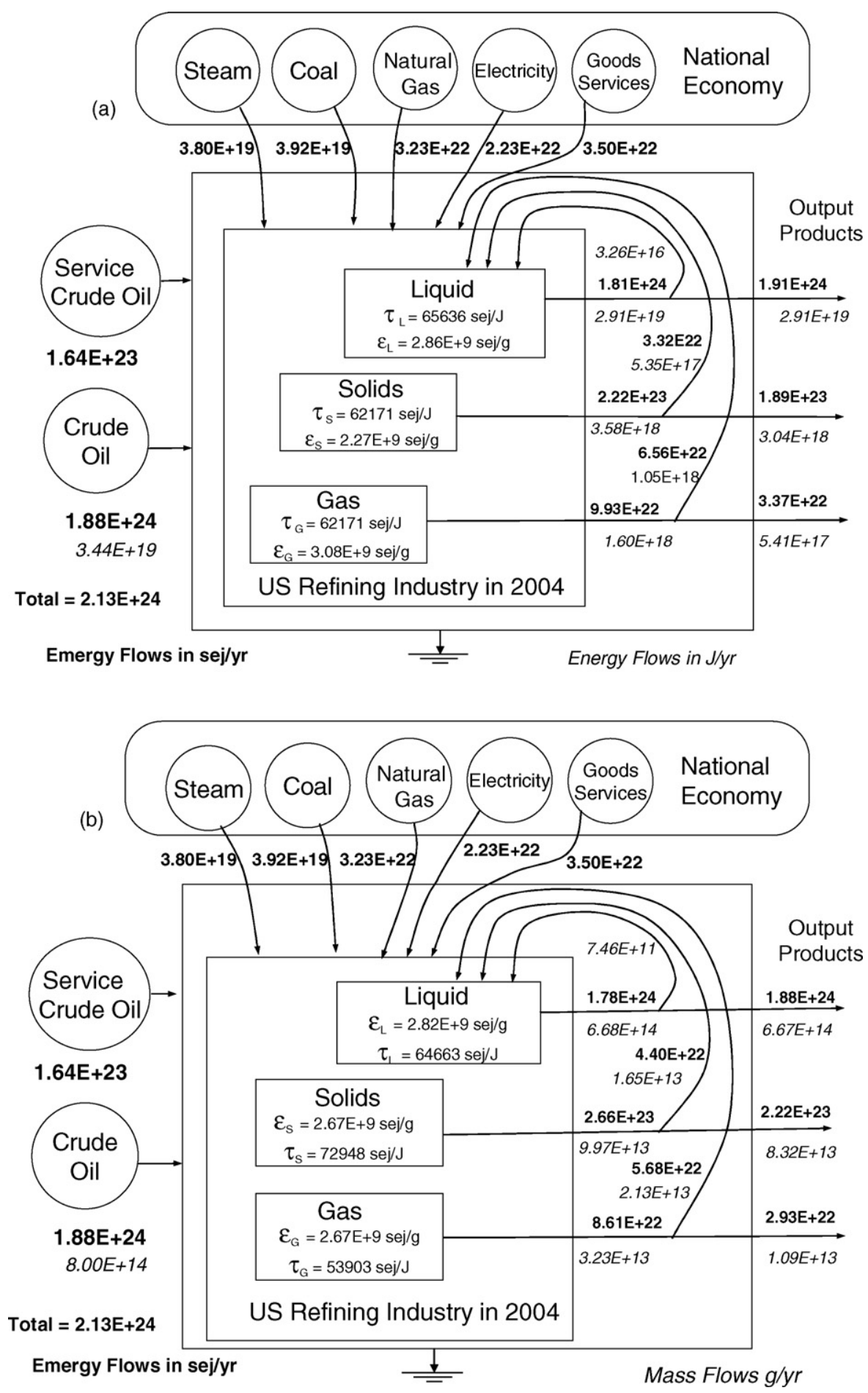

Fig. 3 - ( $a$ and $b$ ) White box energy diagrams of the U.S. refining industry in 2004, considering energy split (a) and mass split (b). The emergy of liquids is derived by adding the emergy contributions of gases and solids (feedbacks) necessary for their production. Emergies are in bold; energies in italic.

process is not optimized for their production and they are just considered as additional production factors. In fact the use of feedbacks substitutes for the use of additional inputs from outside the system.

The mass split (Fig. 3b) gives gases the lowest transformity $(53,903 \mathrm{sej} / \mathrm{J})$ and solids the highest $(72,948 \mathrm{sej} / \mathrm{J})$ with liquids in an intermediate position $(64,663 \mathrm{sej} / \mathrm{J})$. This pattern may be consistent with theory, if solids, liquids and gases are viewed as the same product, i.e., a combustible substance. In this case the higher the heat value the lower the transformity, indicating that a joule of combustible substance in a gas is made more efficiently in the refining process than a joule of 
Table 5 - The emergy per mass of the various refined crude oil products (adapted to the USA classification).

\begin{tabular}{|c|c|c|c|c|}
\hline \multirow[t]{2}{*}{ Refinery products } & \multirow[t]{2}{*}{ Calorific value $(\mathrm{kJ} / \mathrm{g})$} & \multicolumn{3}{|c|}{ Specific emergy (sej/g) } \\
\hline & & U.S. & Falconara & Average \\
\hline Liquefied gases & 47.3 & $3.08 \mathrm{E}+09$ & $3.14 \mathrm{E}+09$ & $3.11 \mathrm{E}+0 \mathrm{~s}$ \\
\hline Motor gasoline & 44.3 & $2.89 \mathrm{E}+09$ & $2.95 \mathrm{E}+09$ & $2.92 \mathrm{E}+0 \mathrm{~s}$ \\
\hline Aviation gasoline & 44.3 & $2.89 \mathrm{E}+09$ & $2.95 \mathrm{E}+09$ & $2.92 \mathrm{E}+0 \mathrm{~s}$ \\
\hline Kerosene-type jet fuel & 44.1 & 2.87E+09 & $2.93 \mathrm{E}+09$ & $2.90 \mathrm{E}+0 \mathrm{~s}$ \\
\hline Kerosene refinery & 43.8 & $2.85 \mathrm{E}+09$ & $2.91 \mathrm{E}+09$ & $2.88 \mathrm{E}+0 \mathrm{~s}$ \\
\hline Total distillate (diesel) & 43.0 & $2.80 \mathrm{E}+09$ & $2.86 \mathrm{E}+09$ & $2.83 \mathrm{E}+0 \mathrm{~s}$ \\
\hline Residual fuel oil & 40.4 & $2.63 \mathrm{E}+09$ & $2.69 \mathrm{E}+09$ & $2.66 \mathrm{E}+0 \mathrm{~s}$ \\
\hline Other oils for petrol. feed & 40.2 & $2.62 \mathrm{E}+09$ & $2.67 \mathrm{E}+09$ & $2.64 \mathrm{E}+0 \mathrm{~s}$ \\
\hline Lubes & 40.2 & $2.62 \mathrm{E}+09$ & $2.67 \mathrm{E}+09$ & $2.64 \mathrm{E}+0 \mathrm{~S}$ \\
\hline Waxes & 40.2 & $2.62 E+09$ & & \\
\hline Petroleum coke & 32.5 & $2.12 \mathrm{E}+09$ & & \\
\hline Asphalt & 40.2 & $2.62 \mathrm{E}+09$ & $2.67 \mathrm{E}+09$ & $2.64 \mathrm{E}+0 \mathrm{~s}$ \\
\hline Still gas & 49.5 & $3.23 \mathrm{E}+09$ & $3.29 \mathrm{E}+09$ & $3.26 \mathrm{E}+0 \mathrm{~s}$ \\
\hline Miscellaneous & 40.2 & $2.62 \mathrm{E}+09$ & & \\
\hline
\end{tabular}

Calorific values are from IPCC (2006). Emergy per mass (in sej/g) is obtained multiplying the transformities (66,490 sej/J for Falconara and 65,162 sej/J for U.S. 1993-2004), common for all the fuels, by the calorific value of each fuel (J/g). Values based on an energy split of the emergy requirement. With respect to the average, the standard error varies from $1.31 \%$ to $1.53 \%$.

liquid, which in turn is made more efficiently than solid fuel. If the petroleum derivatives are viewed as different products, then the transformities based on a mass split are inconsistent with theory. This partial evaluation whether based on mass or energy provides highly uncertain estimates for the transformities of solid and gaseous petroleum derivatives because both solids and gases are consumed in a refining process which is optimized to make liquid fuel. Comparing the results of the two white box scenarios, the transformity and specific emergy of liquid fuels differ by only $1.5 \%$ as a result of using an energy or a mass split to assign emergy. The energy split gives a larger value for transformity and a smaller value for specific emergy than does the split based on mass.

\section{Conclusions}

In this study the calculation of the transformity and of the specific emergies (emergy per mass) of the fuels derived from crude oil, was carried out. The most debated issue for this purpose was how to consider the fuels, i.e., are the petroleum derivatives splits or co-products. Both conceptual and practical considerations converged towards the split hypothesis. This fact allows us to sum the emergies of all the different fuels that feed the same process without problems of double counting. Within the split category emergy was split based on energy rather than mass for several reasons, chief among them was so that the 1st Law of Thermodynamics is in all cases satisfied. Using an energy split we found that the higher the quality (calorific value) of a fuel the higher its emergy per unit mass, which is also evidence that the emergy split based on energy is reasonable.

The evaluations were carried out using data from two regional refinery systems (Falconara, Italy and the San Francisco Bay area, USA) and a national system (the refining industry in the USA). All the results were consistent: so we suggest using a transformity of $65,826 \mathrm{sej} / J$, the average of the Italian and U.S. systems (1993-2004), for use in emergy anal- yses where the origin of petroleum fuels is unknown. The standard error of this result is $1.4 \%$, which is a rough indicator of the uncertainty of the estimate.

Emergy evaluation has received criticism for the calculation of the transformities, sometimes thought to be too fuzzy, i.e., with unspecified uncertainty. In this study we believe that we have made a modest contribution to strengthen the methodology, providing data for some of the most important inputs in the evaluation of systems controlled by human activities and interests that includes a 1st order estimate of the uncertainty in both data and models. These new figures reinforce the validity of previous analyses, since the transformity value derived in a different manner by Odum was only slightly different from the results of this study.

\section{REFERE N C E S}

API, 2005. Rapporto Ambientale 2004 (www.apioil.com), 23 pp. Bank of Italy, web site: http://uif.bancaditalia.it/UICFEWebroot/ index.jsp?whichArea=Cambi\&lingua=en.

Bastianoni, S., Campbell, D., Susani, L., Tiezzi, E., 2005. The solar transformity of oil and petroleum natural gas. Ecological Modelling 86, 212-220.

Brandt-Williams, S.L., 2002. Handbook of Emergy Evaluation: Folio 4. Emergy of Florida Agriculture, Systems Ecology Center, University of Florida, Gainesville, FL.

Brown, M.T., Herendeen, R.A., 1997. Embodied energy analysis and EMERGY analysis: a comparative view. Ecological Economics 19, 219-235.

Brown, M.T., Ulgiati, S., 1999. Emergy-based indices and ratios to evaluate sustainability: monitoring economies and technology toward environmentally sound innovation. Ecological Engineering 9, 51-69.

Brown, M.T., Ulgiati, S., 2002. Emergy evaluations and environmental loading of electricity production systems. Journal of Cleaner Production 10, 321-334.

Brown, M.T., Odum, H.T., Jørgensen, S.E., 2004. Energy hierarchy and transformity in the universe. Ecological Modelling 178, 17-28. 
Campbell, D.E., 2000. A revised solar transformity for tidal energy received by the earth and dissipated globally: Implications for Emergy Analysis. In: Brown, M.T. (Ed.), Emergy Synthesis, Proceedings of the First Biennial Emergy Analysis Research Conference. The Center for Environmental Policy, Department of Environmental Engineering Sciences, Gainesville, FL, USA, pp. 255-263.

Campbell D.E., Brandt-Williams, S.L., Meisch, M.E.A, 2005. Environmental Accounting Using Emergy: Evaluation of the State of West Virginia. USEPA Research Report, EPA/600/R-05/006, http://www.epa.gov/NHEERL/publications/ files/wvevaluationposted.pdf.

Cook, E., 1976. Man, Energy, and Society. Freeman, San Francisco.

EIA, 2004. Petroleum Supply Annual 2004 Volume 1, Table 37. http:/www.eia.doe.gov/oil_gas/petroleum/data_publications/ petroleum_supply_annual/psa_volume1/psa_volume1.html.

EIA Energy Information Administration, 2005. International Energy Annual 2005. Table C.1 General Conversion Factors, www.eia.doe.gov/emeu/iea/tablec1.html.

EIA, 2007. Energy Information Administration. http://tonto.eia.doe.gov/dnav/pet/pet_pnp_top.asp.

IPCC, 2006. In: Eggleston, H.S., Buendia, L., Miwa, K., Ngara, T., Tanabe, K. (Eds.), 2006 IPCC Guidelines for National Greenhouse Gas Inventories, Prepared by the National Greenhouse Gas Inventories Programme. IGES, Japan.

Marchettini, N., Niccolucci, V., Pulselli, F.M., Tiezzi, E., 2007. Environmental sustainability and integration of different methods for its assessment. Environmental Science and Pollution Research 14 (4), 227-228.
Odum, H.T., 1996. Environmental Accounting. John Wiley and Sons, New York.

Odum, H.T., Wojcik, W., Pritchard Jr., L., Ton, S., Delfino, J.J., Wojcik, M., Patel, J.D., Leszczynski, S., Doherty, S.J., Stasik, J., 2000. Heavy metals in the environment, using wetlands for their removal. Lewis Publishers, Boca Raton, FL, 325 pp.

Pizzigallo, A.C.I., Granai, C., Borsa, S., 2008. The joint use of LCA and emergy evaluation for the analysis of two Italian wine farms. Journal of Environmental Management 86 (2), 396-406.

Quinn, A.T., 2001. San Francisco Bay Area Petroleum Industry Economic Impact, Community Value. Western States Petroleum Association, $16 \mathrm{p}$ http://www.wspa.org/pdfs/Nor_Cal_Economic_Impact_Study.pdf.

Raugei, M., Bargigli, S., Ulgiati, S., 2005. A multi-criteria life cycle assessment of molten carbonate fuel cells (MCFC)-a comparison to natural gas turbines. International Journal of Hydrogen Energy 30, 123-130.

Sciubba, E., Ulgiati, S., 2005. Emergy and exergy analyses: complementary methods or irreducible ideological options? Energy 30 (10), 1953-1988.

Slesser, M., 1978. Energy in the Economy. St. Martin's Press, New York, $162 \mathrm{pp}$

Tissot, B.P., Welte, D.H., 1978. Petroleum formation and occurrence: a new approach to oil and gas exploration. Springer, New York.

Williams, J.L., 2007. Oil Price History and Analysis. WTRG Economics, http://www.wtrg.com/prices.htm (accessed 05.10.07) 